\title{
SELVAGENS NA IGREJA A FRISA DE SAINT-JACQUES DE DIEPPE: UM CASODE BRICOLAGEM CULTURAL*
}

\author{
Mary Lucy Murray Del Priore \\ Departamento de História - FFLCH/USP
}

\begin{abstract}
RESUMO: Este artigo trata das relaçōes culturais entre a França e o Brasil no século XVI através da imagem de índios e americanos.

ABSTRACT: This article discusses the cultural relationships between France and Brazil during the sixteenth century through the images of Indians and Americans.
\end{abstract}

PALAVRAS-CHAVE: Arte, Comércio, Renascimento, Brasil, França.

KEY-WORDS: Art, Commerce, Renaissance, Brazil, France.

\begin{abstract}
O navigantz, o povres mathelotz qui congnoisscz la nature et les flotz de la grand mer du pretendez profit levez les ycux, ayant les cucurs devotz devers le cicl, et je scray des vos d donner gloirc a Celluy qui la fit. JEAN PARMENTIER - 1494-1529
\end{abstract}

\section{Descobertas, comércio e Renascimento}

Entre o último quartel do século XV e a primejra metade do XVI, as cidades portuárias francesas foram marcadas por um brilhante desenvolvimento econômico. A paz política $\mathrm{c}$ uma certa fluidez no transporte interno incentivaram trocas em pequena, média e

- Este artigo não teria sido escrito sem a ajuda de Charles M. Lisbona, a quem sou muito grata. Paciente guia na cidade de Dieppe, fez-me conhecer o Thésor de Jehan Ango entre outros tesouros. larga escala. Findo o período das grandes pestes medievais, aceleraçōes no movimento demográfico provocaram um aumento nas demandas e mais: forneceram mão-de-obra atraída pelo aumento de salários, que só declinaram a partir de 1520-1530, em razâo mesmo de sua abundância. Os fatores deste crescimento, explica Janine Garrison (GARRISON, 1991, Pp. 27-37), são bem conhecidos: abertura do mundo, logo, de novos mercados, aparecimento de produtos raros, desconhecidos até entāo, a redistribuição na Europa ocidental dos tesouros resultantes do ouro e da prata americana via Espanha (MAURO, 1966, pp. 213-214).

Neste cenário, os grupos mercadores revelaramse portadores de um impressionante dinamismo. 
Aqueles a quem os documentos qualificam simplesmente de marchands, traficavam todo o tipo de produtos contanto que fossem vendáveis em seu raio de ação. Sua clientela pertencia a todos os meios sociais, desde o camponês, comprador de sementes ao gentilhomme consumidor de veludos de Gênova e cetins de Milāo. Contudo o comércio não lhes bastava. Emprestavam dinhciro aos nobres, à Igreja, aos cultivadores; coletavam dízimos eclesiásticos, instalavam-se $\mathrm{cm}$ magistraturas municipais. No século $\mathrm{XVI}$, comerciantes e burgueses de toga, os chamados robin, partilhavam a gestão urbana. Aqueles de maior envergadura substituíram, na França, banqueiros como os Fugger ou os Welser, atuando por meio de lctras de câmbio que evitavam o transporte monetário oneroso $\mathrm{c}$, sobrctudo, perigoso.

Essa burguesia comercial que traficava incansável sobre as rotas e mares do mundo - "que conhecia como Ulisses, os mores de muitos homens e estudando e comparando-os, bebia nas experiências intercambiantes, o sentido precioso do rclativo" (FEBVRE, 1983, p. 53) - tinha, então, duas necessidades: a primeira, a do saber. Tudo atraía a burguesia a conhecer o Oriente de mirabílias, os tesouros das Índias: vestígios da Antigüidade, ruínas, velhos manuscritos, plantas desconhecidas e animais singulares - os povos, sua linguagem, costumes, vestimentas e crenças. A segunda, uma forma de religiosidade que the servisse simultaneamente como luz e apoio. Nesse artigo vamos tratar da religiosidade de um comerciante seiscentista e das implicaçōes do Novo Mundo em sua piedade.

\section{O homem do mar}

Localizada na Alta-Normandia, a cidade de Dieppe, juntamente com Rouen, Fécamp, Honfleur, constitui um núcleo de portos que se abrem para a Mancha. Num contexto de intensas trocas mercantis que assegurava a presença de uma rica burguesia lo- cal, Dieppe teve sua prosperidade confirmada, como escoadouro das feiras de Anvers, a partir do século $X V^{\prime}$. Aproveitando-se do momento favorável, JeanAngo, banqueiro ruanês, tornou-se em 1463 armador $^{2}$ graças à proteçāo do chanceler Jorge I de Amboise, Arcebispo de Roven e senhor temporal de Dieppe. Ao sucedê-lo, scu filho e herdeiro Jehan tinha entāo, trinta anos. Ele seria o homem do arcebispo Jorge ll de Amboise (1510-1550) e do rei Francisco l, "son bon maître" (1515-1547).

Esses cram tempos em que a carga trazida pelos navios espanhóis do Novo Mundo criava enorme impressāo na Europa; tempos também, em que marinheiros bretōes reconheciam as baías da Terra-Nova, carregando seus porões de peixes ou que normandos de Honftcur, perseguindo a rota de Vasco da Gama para as Índias Oricntais, viram seu barco, o Espoir, atirado por uma tempestade às costas brasileiras $\mathrm{cm}$ $1503^{3}$. A rica carga que transportavam desapareceu no naufrágio e os comerciantes que haviam investido no negócio ficaram desencorajados pelo acidente. Ango, pelo contrário, retomou a iniciativa, diversificando e ampliando os negócios paternos: ele procu-

1. Em Outono da Idadc Media ou Primavera dos Novos Tcmpos, Philippe Wolff introduz o cenário mercantil do século XV, sobretudo na segunda parte do trabalho: Joāo que ri, pp. 95-189. Michel Mollat du Jourdin $\mathrm{cm} \mathrm{L'Europe} \mathrm{ef} \mathrm{la} \mathrm{Mcr}$, Paris, Seuil, 1993, p. 156, recupern o mapa das vias marítimas curopéias na Idade Moderna, locatizando Dienpe nas suas relaçōcs com outros portos como Merseille, Bristol, Lisboa, Trípoli, Alexandria, etc.

2. Armadores no século XVI são considerados, na França, os "Bourgeois du navire"; tanto podiam administrar uma flotilha com capitais próprios como, com empréstimos. Eram considerados tambem armadores, os associados, ou parsonnicrs, e esses, ora estavam associados em permanência a uma companhia, quanto podiam associar-se a uma viagem, a um barco, a um "risque dc mer". Jean Favier em Lcs grands découvcrtes - d'Alcxandre à Magellan, Paris, ArthémeFayard, 1991, pp. 357-367, explica com minimos detalhes as atividades comerciais e financeiras que incluía o oficio do armador.

3. Sobre este episódio veja-se Leyla Perrone-Moisés. Vin1e Luas: Viagem de Paulmicr de Conneville ao Brasil, São Paulo, Cia. das Letras, 1992. 
rava atingir as Índias, contornando a América do Sul ou pela rota lusa do Cabo da Boa Esperança, tanto para fazer comércio marítimo de grande escala quanto para expediçôcs de descobrimentos.

Esses, também, cram tempos em que o armador revesava-se entre o corso ${ }^{4} \mathrm{e} o$ comércio ${ }^{5}$. Não contente em enviar ao mar barcos solidamente bem armados, com canhōes e marinheiros intrépidos, Ango reunia esquadras que postavam-se em lugares estratégicos, para fazer presas de maior valor. O cabo Sāo Vicente, ao sul de Portugal, ponto corriqueiro de passagem dos navios chegados da América era, particularmente, indicado para esses assaltos e, em 1521, os corsários de Ango capturam três caravelas carregadas de mercadorias para os comerciantes de Sevilha". Em 1522 nos Açores, Jean de Fleury, a serviço do armador dieppois, realiza a mais bela captura jamais feita por um corsário: o tesouro dos reis do México enviado por Cortez em três caravelas. Tratam-se das riquezas pilhadas pelos espanhóis no palácio de Guatimozin: máscaras em mosaico de pedras finas, jóias esplêndidas, objetos de uso cotidiano, vestimentas em plumas e milhares de discos e ídolos $\mathrm{cm}$ ouro ${ }^{7}$.

4. Sobre a correta designação para Ango enquanto armatcur capaz de pilhagem ver o artigo de J.S. Bromley, "Bandidos no Mar, 1660-1720: Liberdade, Igualdade e Fraternidade entre os Flibusteiros do Caribe" em A Outra His. tória - Idcologia c Protesto Popular nos seculos XVII c XVIII, org. Frederick Krantz, Rio de Janeiro: Zahar, Pp. 244-265. Agradeço a Marcelo de Paula Conceição a gentileza da indicação deste artigo e dos demais livros sobre pirataria.

5. Dentre as mercadorias descarregadas no porto de Dieppe destacam-se a pimenta $\mathrm{e}$ as especiarias sob as quais o arcebispo de Rouen linha direitos de pagamento: "Le churgrc, le gingembre, la malaguette et le chitonac...". Pierre Bazin. Conservatéur du Musée de Dieppe. "Points de Départs", in Vicilles Maisons Françaiscs - Patrimoinc Historiquc, n" 147, pp. 26-31.

6. Para conhecer melhor a siluação do comércio luso entre os séculos XV e XVI veja-se Vitorino Magalhães Godinho. Os Descobrimentos e a Economia Mundial. Lisboa: Editorial Presença, 2 vols., 1963-1971.

7. Para essas e outras informaçōes sobre Jehan Ango, vejase Jean Merrien. Histoirc des Corsaircs, Paris, Amiot-Dumont, 1954.
Ango ocupava-se, igualmente, de todas as missōes essenciais à França: defesa do litoral, guarda do Pas de Calais, comboios de navios para a Escócia, escolta de pescadores da Terra-Nova e, como já foi dito, captura de galeões espanhóis. Mas também, portugueses.

A França não estava, entāo em guerra com Portugal, mas o governo luso tinha. sérias queixas contra os franceses que obstinavam-se, malgrado a bula papal, em comerciar com o Brasil. Francisco I nāo se cansava de contesțá-la: "Je voudrais bien voir - dizia ele - la clause du testament d'Adam qui m'exclut du partage du monde. Le soleil ne luit-il pour moi comme pour les autres?"'.

Portugueses, todavia, ancorados no que thes parecia um dircito inalienável, faziam valer sua hegemonia nas novas terras e mares, recém-descobertos. João III, em 1522, ordenara que seus capitães afundassem, sem misericórdia, os navios franceses encontrados nas Indias da América. Desenrolou-se entre os dois países uma guerra surda, mas atroz. Uma pequena colônia fundada pelo barāo de SaintBlancard na ilha de Santo-Aleixo, perto de Pernambuco, foi destruída e sua guarniçăo selvagemente massacrada. Três navios franceses que carregavam pau-brasil na baía de Todos os Santos foram afundados pelas caravelas portuguesas, e seus marinheiros enforcados ou enterrados vivos. Ango solicita ao rei lettres de marque contra os lusos, utilizando, como argumento, a represália comercial; elas lhe sāo acordadas em 1531.

Começa, assim, uma luta entre os armadores de Ango e os ibéricos, pela primeira vez de acordo: $\mathrm{D}$.

8. Em 1493, o papa Alexandre VI divide o mundo por uma linha imaginária para por fim a quercla hispano-portuguesa. O traço ficticio passa a cem léguas das ilhas de Cabo Verde. Essa bula tem o nome de Intcr Coctcra e segue-se a ela, o Tratado de Tordesilhas (1494).

9. Cartas dadas pelo rei, indicando a proveniência da frota c a bandeira sob a qual navegava. 
João III solicitara a ajuda de Carlos $V$ e o assunto passa para a esfera da diplomacia. Francisco I, apesar de sua defesa pela liberdade do comércio marítimo, abandona Ango: "Ce n'est pas moi qui vous fais la guerre, mais Ango: arrangez-vouz avec lui" (THOMAZI, 1978, pp. 36-52).

Desgraçadamente traído pelo almirante Brion Chabot, antigo associado, que se deixara comprar por 10000 escudos, Ango foi obrigado a renunciar à sua lettre de marque. Năo renunciou, contudo, ao Brasil, onde seus pilotos acreditavam ser capazes de conquistar as boas graças dos indígenas. $O$ comércio com as Antilhas, o Brasil, a Guiné e o Marrocos foi fecundo até 1542. Sob o reinado de Henrique II sucessor do bon François, o adversário nāo vinha mais da Península lbérica, mas da lnglaterra. Ango é encarregado de operaçōes navais, organizando e financiando, em 1.545, a maior expediçáo marítima francesa nesse século contra os vizinhos ingleses. $O$ tesouro real, bem mais frágil, é incapaz de reembolsá-lo e ele morre, arruinado em 1551.

\section{O homem do Renascimento}

Ango foi, em toda a acepção do termo, um homem do Renascimento. Ao mesmo tempo em que conquistava o mundo, detinha o controle dos grĩos e do sal que entravam em Dieppe (1512), exercia o cargo de conselheiro da câmara da cidade (1527) e de coletor de impostos temporais para o arcebispo de Rouen, foi feito capitão do rei (1536) e administrava suas terras com o mesmo entusiasmo que animava um salāo literário.

Seu hôtel ${ }^{10}$ situado na parte nobre do cais de Dieppe, que ele denominara La Pensée em homenagem a um barco paterno, o primeiro de origem francesa a abordar a América do Norte, distinguia-se pelos

10. Denominam-se hotcl de ville as ricas e imponentes casas patrícias, geralmente ocupadas por um abastado particular e sua família e localizadas em zona urbana. terraços à italiana e as boiseries esculpidas e douradas. O cronista Asseline descreve-o em 1682, como coberto de "un si grand nombre de sculptures et de répresentation d'histoire et de fables, que ce lieu passoit, sans contredit, pour un des plus magnifiques" (DUPUIS, 1992, p. 4). Sua casa de campo em Varengeville, dominando um imenso horizonte, tinha o aspecto um pouco carregado de palácio florentino c abrigara em 1533 o próprio rei em visita a seu sócio. Lá, entre afrescos e fachadas decoradas, acotovelavam-se mercadores e pilotos, artistas e poetas de todas as origens. Entre esses, Margarida de Angoulême, a irmā poetisa e mística de Francisco I e Jcan Parmentier, o navegador da Guiné, Terra Nova e Brasil, ganhador, durante dez anos seguidos, do prêmio de poesia em Dieppe e Rouen, concorrendo com o famoso Clément Marot. Outro habitué, Giovanni da Verrazzano, cartógrafo notável, era um letrado erudi. to além de grande amigo de famosos artistas italianos da época". As festas dadas por Ango, conhecidas pelo luxo, atraíam convidados vindos até de Paris. Numa delas, encenou-se uma peça de teatro intitulada Les Biens, na qual figuravam inúmeras imagens resgatadas do contacto com as Índias:

Tubal avec la simarre d'un mandarin chinois; Alexandre le Grand, vêtu de velours cramoisi, galonné d'or, étail porté sur un drap d'or par huit nègres, sous un dais en plumasseries indiennes; son trône était fait de lames d'or massives tailles en forme de serpents (THOMAZI, 1978, p. 45).

Ango era também um piedoso. Como sua amiga Margarida de Angoulême, era um adepto da devotio

11. Empresto aqui algumas informaçōes extraídas de Jean Merrien, op. cit., p. 51. Segundo Jean Delumeau em A Civilizaçăo do Rcnascimento, Lisboa, Editorial Estampa, 1984, vol. I, p. 60, Verrazano era nascido $\mathrm{cm}$ Florença e aparenı. do com os Rucellai. Suas viagens teriam por alvo alcançar "O Catai c o extremo oriental da Ásia". Na tealidade Verrazano, a quem se deve a descoberta do estuário do Hudson, apenas pode realizar a ligação entre a Flórida espanhola e as regiōes descobertas pelos portugueses na regiño da Terra-Nova. 
moderna, despojada forma de piedade que encontrou muitos adeptos entre as camadas dominantes letradas, pois que exigia o suporte do livro $A$ Imitação de Cristo, de Thomas Kempis. Convidando ao desapego do mundo e ao constante diálogo com o divino através de uma relação íntima, a devotio moderna deixava o crente livre das injunçōes da Igreja, incentivando-o a viver a sua piedade de acordo com a sua cultura e as suas preocupações cotidianas. Membro da confraria da Charité de Honfleur, Ango havia dedicado uma bela capela a Saint Yves de Vérité, patrono dos marinheiros bretōes. Em Dieppe, na igreja dedicada a Saint Jacques, um dos últimos exemplos do gótico flamboyant, mandara erguer um oratório para realizar em privado suas preces e presenteara a paróquia com uma frisa no chamado Mur du Trésor. Trata-se de uma das mais insólitas representaçōes até então executadas sobre os Novos Mundos. Retrato da irrupção do profano na concepção de sagrado, ela harmoniza, elegantemente, a sensibilidade religiosa da época com uma síntese de representaçōes sobre o mundo e a natureza que entāo se descortinavam graças às navegações e a correspondente viragem na história material e espiritual da Europa.

\section{A frisa dos "Selvagens"}

No interior da igreja gótica de Saint Jacques ${ }^{12}$, sob a abóbada do corredor do côro, a segunda capela é ornamentada, de alto a baixo, pela mais rica escul-

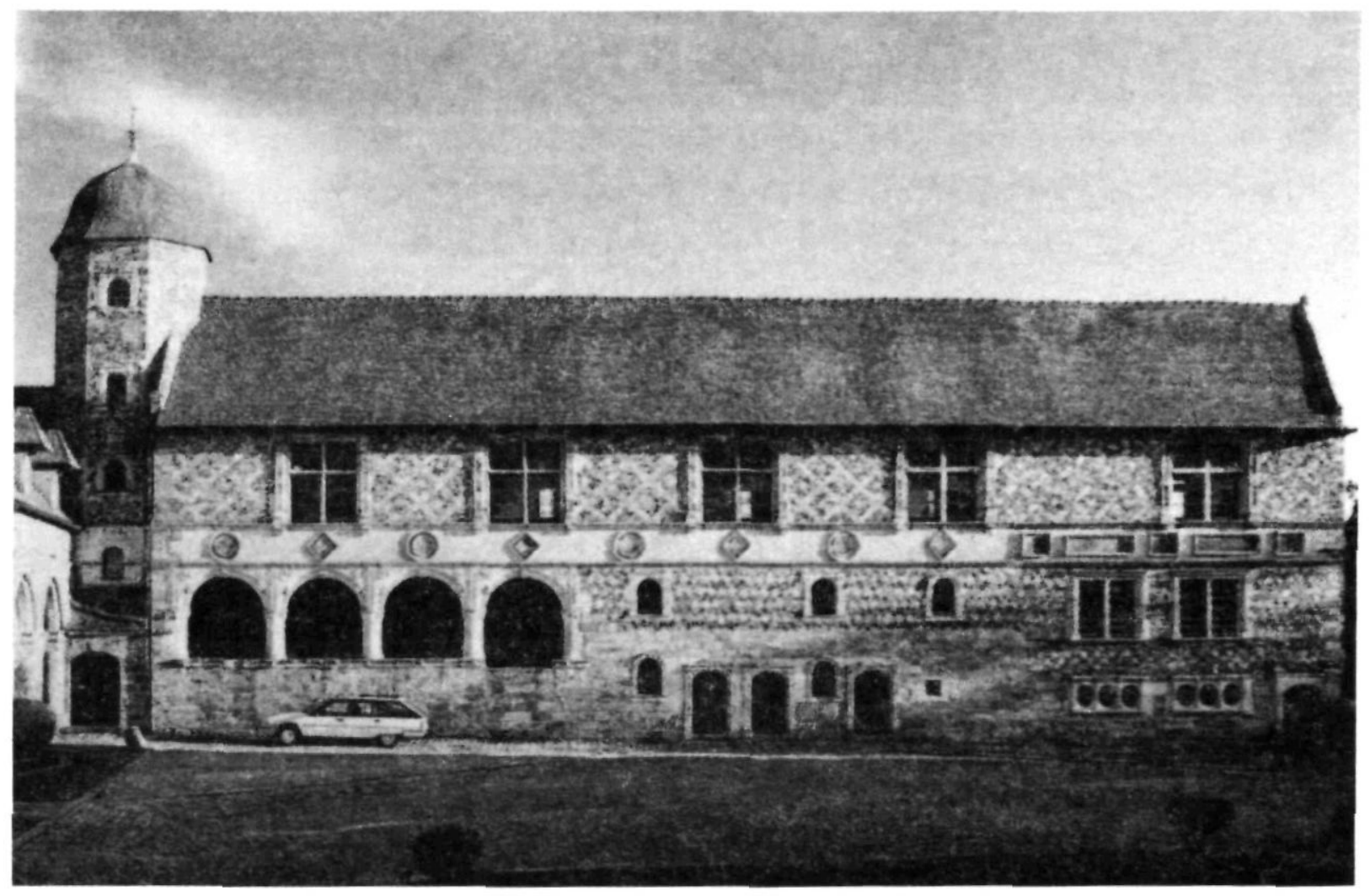

Figura 1. Monoir de Jehan Ango - asa sul plano elevado sobre o pátio interno - Varengeville-sur-Mer. 
tura. Atrás de sua parede central, fecha-se uma pequena sala, na qual se reuníam, no período medieval, os tesouros da paróquia, e onde, durante o Renascimento assembléias deliberavam sobre os negócios da paróquia: cla é chamada ainda hoje le Trésor ${ }^{13}$. Na fachada que dá para a nave central, o anônimo artista contentou-se em extrair da pedra todos os graciosos caprichos do estilo corrente durante o Renascimento: arabescos, medalhöes redondos com animais fabulosos, pássaros alternados com cenas alegóricas, um adorável rclevo de Adão e Eva.

Suportada por cinco pilastras de base alta, separada por sete pequenos nichos pouco profundos terminados cm concha, a cerca de 20 pés do chão, encontra-se a frisa dos selvagens: a cena decididamente nāo se passa na Europa.

O primeiro grupo é composto por três personagens: um homem, uma mulher e uma criança. Com penachos de plumas à cabeça e nus não deixam dúvidas quanto a ser a representaçāo de índios brasileiros. Tanto o homem quanto a mulher vestem um cinto com plumas; a mulher traz ainda um colar também em plumas; tem à māo uma grande folha de palmeira, na outra um cetro ao qual se pendura a criança. $O$ homem está armado com um arco e nas suas costas, vêse um feixe de flechas.

O segundo grupo tem outras características: um

12. A consırução desta igreja escalonou-se entre o últjmo quartel do século XII ao século XVI. Entrando pela porta principal, o visitante descobrirá um edifício uniformemente gótico, até o momento em que se deparar com a parede do Trésor. Ai, como explica François Dupuis, op. cit., p. 12, "en découvrant le décor renaissant de la porte, piédroits et lintenu, la colonne spiralée qui la jouxte et la pilastre auquel elle s'adosse. Le dèambulatoire conduit au petit oratoire d'Ango où l'on change de monde!". O visitante tem sob seus olhos um mundo de registros sobrepostos com animais fabulosos, indios brasileiros, negros, sátiros, Adāo e Eva, as armas de Ango, num caleidoscópio de imagens à mancira dos groteschi do Renascimento italiano.

13. Mniores informaçöes sobre o Trésor em A. Legris. L'Église Saint-Jacques dc Dicppc - Notice Historique et Descriptive. Dieppe: G. negro, uma negra amamentando sua cria, e uma criança dançando como se estivesse saindo de sua choupana; o negro carrega duas zagaias na māo esquerda e com a direita, vibra outra, acima da cabeça; sua muIher e ele trazem às orethas, imensas argolas; todos estāo nus.

Entrc o casal, vê-se enrolada a um tronco, uma imensa serpente. Sobre o galho da mesma árvore, um pássaro (um papagaio) observa a cena.

O terceiro grupo é composto, como os dois outros, por uma "família", ou seja, um homem, uma muIher e uma criança. Mas aqui os personagens tem novas características. Para começar possuem vestimentas; o homem traz um pequeno manto e uma canga enrolada à volta dos rins. $O$ resto do corpo cstá nu, salvo a cabeça enrolada num turbante com uma espécie de "queixera". A mulher apresenta-se coberta com um amplo véu que a cobre da cabeça aos pés; traz ainda uma canga amarrada aos quadris. A criança desnuda, porta apenas um capacete de feitio hexagonal sobre as orelhas.

A América, as costas da Guiné e as costas da Índia (Moçambique ou Madagascar) estão aí, bem representadas, como uma amostra dos três povos freqüentados pelos dicppois, na época $\mathrm{cm}$ que a escultura foi realizada (c. 1530) ${ }^{14}$. A seguir, sucedem-se várias figuras, misturadas, sem aparente articulaçāo narrativa e sem deixar supor uma ação comum entre elas.

Um selvagem americano isolado, com cocar de plumas e alfanje à mão esquerda apoia-se a uma árvore como se quisesse arranći-la do solo.

A seguir, seguem-se seis figuras; três homens nus, armados de escudos e lanças. O quarto personagem porta na cintura uma aljava cheia de flechas. Seu braço direito, hoje quebrado, carregava, sem dúvida,

14. Este é o parecer de M. L.Vitet, inspetor geral dos monumentos históricos da França em seu Histoirc des Ancicnnes Villes de France, Paris, Alexandre Mesnier, 1833, pp. 112-131. 


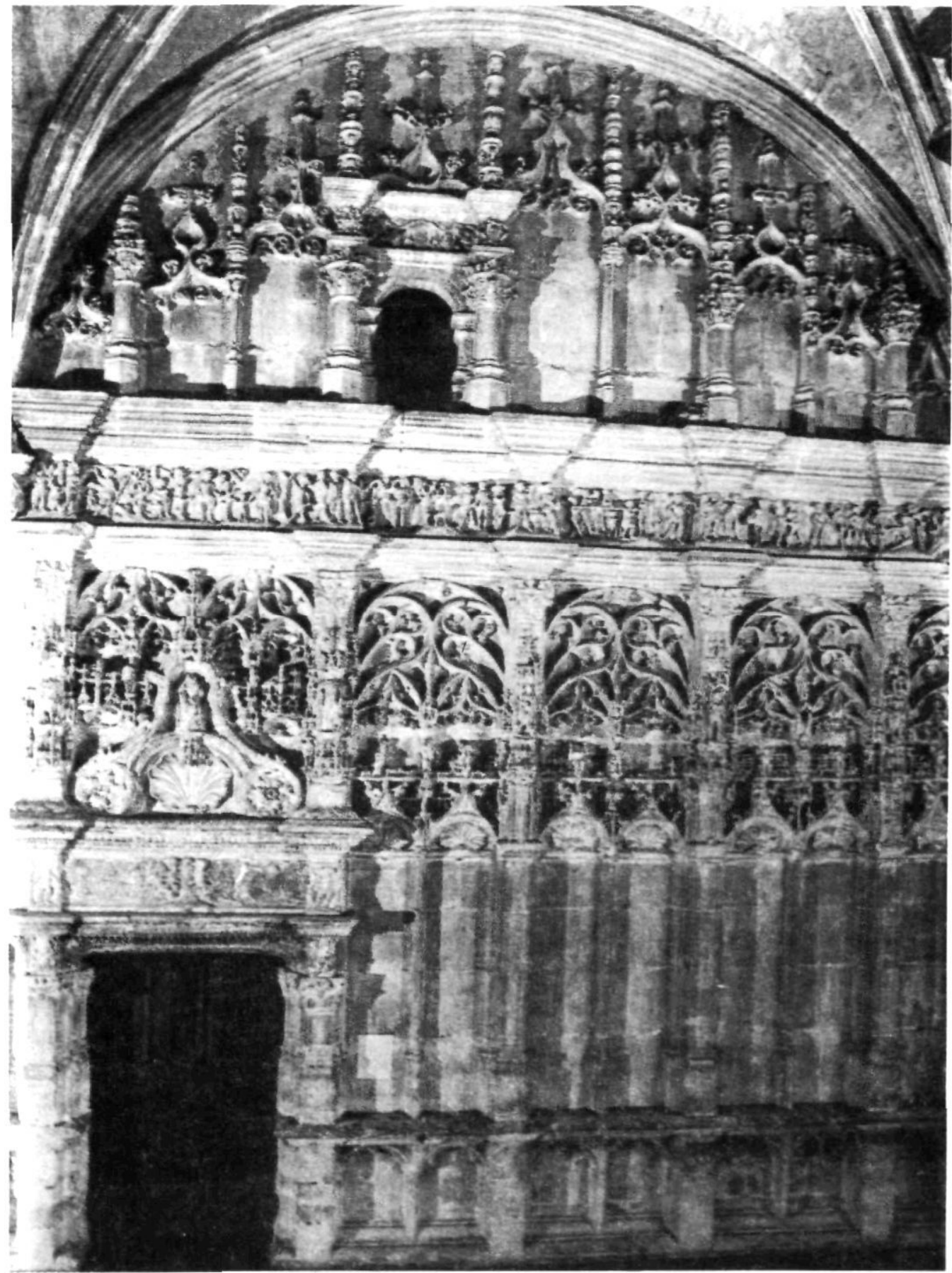

Figura 2. Parede do Trésor de Ango - Igreja de Saint-Jacques, Dieppe. 
um arco; ele é talvez, um chefe. Mais à frente vê-se um selvagem, em ferros, cujos cabelos amarrados atrás da cabeça anunciam uma diferente atnia. É sem dúvida um prisioneiro escravizado, sendo conduzido por um sexto elemento. $O$ "chefe" traz à cabeça um turbante e seus rins estão cobertos com uma canga. Entre eles, uma copada árvore serve de moldura para um haüt, ou bicho-preguiça e um macaco. Os guerreiros estāo todos nus, usam os cabelos compridos, colados às têmporas c cnrolados no pescoço; trazem nos braços pulseiras de plumas e escudos, alguns $\mathrm{cm}$ casco de tartaruga, outros em plumas.

Os dezessete personagens seguintes concorrem, sem dúvida, para uma ação comum: uma cerimónia religiosa? Os dois primeiros personagens, vestidos com um saiote e um turbante tocam respectivamente uma corneta e um tambor. Num palanquim, uma criança despida, scntada, é carregada por quatro adultos. Esses trazem turbantes afunilados e vestem-sc com cangas. Sob o palanquim, outra criança acompanha o cortejo, também nua. Seguem-se quatro negros com diferentes instrumentos musicais: tambor, maracas, pífano. O primeiro traz à māo, uma acha. Um casal, nu, com adorno nas cabeças, dança cnlaçado à maneira européia. Separados por um arbusto ainda dois personagens: um toca um tambor passado no ombro $e$ outro, carrega uma lança.

A última cena mostra um grupo de árvores e arbustos à maneira de Giotto, sobre as quais penduram-se três chipanzés (ou lêmures), cujas posturas semi-humanas parcecm quercr lembrar o parentesco animal entre todos os membros do baixo-relevo.

Pequenas figuras semcadas ao longo da fachada do trésor mantém com a frisa uma relação harmônica; macacos, pássaros, homens nus, no meio da pilastra central acompanham o resto da composiçāo do baixorelevo.

Atrás de cada nicho dissimula-se uma intenção que visa convencer, propondo a seu obscrvador uma correta compreensão do texto esculpido. No seu con- junto, a frisa dos "selvagens", cristaliza uma estória, uma propaganda, um ensinamento: um clogio ao presente e ao seu valor civilizacional. O Renascimento é a época de todos os possíveis, de todas as audácias. O homem - no caso, Ango - está no centro do mundo, lugar geométrico para onde convergem todos os humanistas. O otimismo ć seu mote pois o indivíduo é capaz de ultrapassar-se por meio de sua cultura, de sua educaçāo c da ćpoca impressionante cm que vive. Elitismo é a sua característica, pois os humanistas consideram que fora do conhecimento nāo há salvação. A humanidade progride para o melhor graças aos esforços terrestres desta elite de saber $\mathrm{c}$ inteligência.

Nesse horizonte, o Outro, negro, indio ou mouro é fruto exclusivo da natureza - natureza que se opōe à cultura - além de ser anticristão; e o cristianismo é o denominador cultural entre quem doa a frisa $c$ quem a observa. Logo, Ango e devotos da paróquia de Saint-Jacques "liam" a frisa como uma mensagem da piedade tradicional mas também como um cloqüente testemunho de um mundo - aquele descortinado pelas navegaçóes - para a qual a Igreja mostrava-se até então, fechada: "tanto mais - explica Lucien Febvre - quanto o clero, e sobretudo, os teólogos, ignorantes das coisas do seu tempo e aliás, mediocremente curiosos em conhecê-las, continuavam a viver com os olhos fechados a toda a realidade" (FEBVRE, op. cit., p. 56).

A realidade que conheciam o comerciante e seus conterrâneos, incluía o universalismo característico do período: todo o homem era depositário da humanidade intcira. Mas de uma humanidade dividida por suas diferenças. E o Outro da frisa, é basicamente aquele que se enquadra na diferença; nas singularidades religosas, físicas, morais e matcriais reveladas pelas "descobertas" e exploraçóes de novas terras. Não cristão, "primitivo", ele é também aquele que está vestido de forma diversa. $\mathrm{E}$ isto a um tempo em que a roupa, näo contente de distingüir o homem do animal, torna-se também um costume e um elemento 
fundamental de discriminação social e cultural. A representação da nudez de índios, negros e mouros ou a escolha de seus objetos vestimentares (cocares, lanças, tambores, etc.) reportava-se à influência da dupla herança, bíblica e mitificante, que estruturava, então, a cultura européia e cristã; essa representação oscilava entre a idéia de uma nudez vergonhosa, devido ao impudor e à indulgência, e aquela outra motivada pelas descobertas greco-latinas, de uma nudez gloriosa, símbolo de inocência's ${ }^{15}$. Ambas avalizavam a presença desnuda dos selvagens na igreja.

A imagem de estranhamento e perigo, suscitada pelas figuras guerreiras e armadas na série de nichos, cristaliza ensinamentos explícitos sobre os espaços c as gentes conhecidas por Jehan Ango. Atrás de tais imagens, a cristandade européia representada por meio do doador, projetava-se como superior, poderosa, rica, remida pela fé e consagrada pelo avanço técnico. Sua relação com os personagens do Novo Mundo traduzia-se num misto de nostalgia dos mitos cruzadísticos, bem vivos até esse momento, e o apelo dos prazeres da experiência representada pelas navegaçōes.

Os "selvagens da frisa" serviam assim, para afir. mar a devoçāo de Ango, seu conhecimento sobre o mundo e para sublinhar as diferenças que, enquanto ser culturalmente "superior", impingia aos que the eram diversos.

\section{A função da escultura na igreja entre os séculos XV eXVI}

Em seu A Civilização do Renascimento, Jean Delumeau explica que, ao final do século XV, tendências profundas impeliam a arte européia em novas di-

15. Para o tema da vestimenta, veja-se Nicole Pellegrin. "Vêtements de peau (x) et de plumes: la nudité des indiens" em Voyager à la Renaissance, Paris, Maisonneuve \& Larose, 1987. Para o tema dos índios e negros na cartografia do século XVI, veja-se o meu "Retrato da América quando Jovem", reçōes. Abandonando os caminhos do idealismo, os artistas abriam os olhos para a realidade cotidiana, descobriam a paisagem, integravam as misérias e a diversidade humana ${ }^{16}$. Na França, além da apropriação destas tendências, incorporou-se ao gosto estético, a busca de ornamentos e decoração resgatadas na Antigüidade:

A exuberante e fantástica fachada da cartuxa de Paiva o monumento de Itália que os franceses mais admiravam verdadeira festa de mámores e esculturas, fornece o melhor exemplo da fantasia com que o Renascimento italiano utilizou, por vezes, o vocabulário artístico dos Antigos. Medalhōes com os imperadores de Roma ou com os rcis do Oriente, cenas alcgóricas e mitológicas, grinaldas, pilastras finamente cinzeladas, aves diversas recobrem a parte inferior que é do fim do século $X V^{17}$.

Sua influência é visível nos palácios do vale do Loire, na Bretanha e na Normandia, onde generalizouse esse tipo de "quadro" separado dos outros por colunas torcidas e caneladas, cercadas de arabescos, conchas, putti, faunos golfinhos, máscaras e nus. Ambas as tendências veremos reproduzidas no Trésor doado por Ango. Esta decoração compósita era aplicada à arquitetura gótica, numa mistura de tradição local com referências bebidas na fantasia infinda de Primatício ou Serlio, visitantes italianos à corte francesa.

Além de revelar a apropriação de tendências artísticas a cavaleiro entre a baixa Idade Média e o Renascimento, a doação do Trésor à igreja de Saint-Jacques enquandra-se em outra característica da vida religiosa no ocidente quinhentista: o ascenso e a afirmaçāo da devoção leiga.

O cristianismo, que até então fora uma religiāo de clérigos que enquadravam e dirigiam a devoçāo docil dos fiéis,

em Estudos Históricos $n^{2} 9$, América, 1992, Fundaçāo Banco do Brasil, Editora Fundação Getúlio Vargas, pp. 3-13.

16. Op. cit., pp. $92-93$ e passim.

17. $I d c m$, p. 106. 
tomou novas cores. Passou a exprimir, numa civilização mais urbana, uma alma coletiva mais autônoma e menos controlável que anteriormente.

\section{Ainda Delumeau ${ }^{14}$ :}

Assim sendo, desenvolveram-se confrarias, multiplicaram-se festas religiosas, autos de fé c procissões, fundaramse coros e oratórios privativos nas igrejas ${ }^{14}$ nos quais guardavam-se reliquias, onde rezavam-se as oraçōes da manhā e da noite, liam-se as Horas e meditava-se diante das imagens sagradas. A fé afîrmava-se por meio de expressōes individuais, mas também coletivas de participaçāo na doutrina, na instruçāo religiosa, na veemência inusitada com que se afirnava a pertença a uma religiāo $0^{20}$.

A doaçăo revelava ainda, outra característica moderna: aquela da individualidade do cliente. Ango encomendara uma obra com temas profanos, afirmando seu poder e personalidade através de uma dupla apropriação do espaço da igreja: aquela privada, pois trata-se de scu oratório particular; c a pública, pois ela é oferecida à vista da comunidade.

Seu símbolo heráldico, manifestação da apropriaçāo do mecenas sobre a obra que provocou - e os goteschi. de inspiraçāo italiana e cortesā - emblemas de sua intcgraçāo a uma cultura culta e aristocrática -, somam-se às imagens das terras e gentes que ele conhecia, com as quais mercadejava e a quem queria estender as benesses da fé católica; tais eram as marcas pessoais do armateur reveladoras à comunidade, de seu fausto, fortuna e história ${ }^{21}$.

18. Idem, p. 136.

19. Uma nítida reproduçāo do oratório privado de Jehan Ango pode ser encontrada em Histoire de la France Raligicusc $-X I V * X V I I /$ sićcles, org. Jacques Le Goff e René Rémond, Paris, Seuil, 1988, vol. 11, p. 206.

20. Vale sublinhar que o primeiro quartel do século XVI é pródigo no que Le Goff chamou de "febre de construçōes". Atendendo a fase de repovoamento e reconstrução da França, remodelam-se igrejas, com ampliação de naves, coroamento de torres c reforma de tetos na regiāo de Paris, na Normandie, (em Harfleur, Fécamp, Rouen, etc.) e na Provencc. Em Dieppe, este é o caso de Saint-Rémy. Op. cit., p. 195.

21. Sobre as doaçōes e o sistema de patronato que ligava as comunidades e os artistas no final da Idade Média, veja-se
O lugar do Trésor é, também, interlocutor da relação que teriam entre si, a obra, o doador e a comunidade. Localizado no coro, ele constituía um mundo sagrado artificial. Semelhantc à fachada de uma catedral imaginária, transportado para o interior da nave, o Trésor focalizava a atenção do espectador c suas possibilidades técnicas incentivavam toda uma riqueza de ensinamentos visuais. Revelando pequenas cenas, o Trésor de Jehan Ango, parece querer confundir a linha que separava o mundo da arte do universo cotidiano do doador; o grande cuidado no modelado da obra, procurava transmitir vida ìs figuras de negros $\mathrm{e}$ índios ${ }^{22}$, trazendo-os para o interior de sua cultura hegemônica: a ocidental cristã. Possuir o mundo, durante o Renascimento, significava conhecê-lo. O conhecimento, por sua vez, era sinônimo de poder. A arte, cabia glorificar este poder, e ela o faz tendo como referência personagens dc um outro mundo, aos quais se representa, prisioneiros da pedra, da igreja e do poder do conhecido comerciante.

Por fim, o Trésor é um espelho das representaçōes que se faziam os homens do Renascimento sobre o além-mar, inscritas numa concepção específica de natureza; natureza que significava a diversidade como símbolo tangível da presença divina no mundo. Natureza quc, ao introduzir o desconhecido, incentiva à emoçāo, à meditaçāo. Ao doar à sua paróquia um tal retrato da natureza, Ango extende à comunidade a possibilidade coletiva de participar deste mistério, e incentiva o historiador a algumas questōes como: Que migrações podem ter ocorrido entre as figuras

Georges Duby. O Tcmpo das Catcdrais - A Arte c a Socicdadc, Lisboa, Editorial Estampa, 1979, especialmente o capitulo 8, "Homens Novos", pp. 191 e passim.

22. Sobre escultura em pedra ou madeira durante este período ver o bclíssimo livro de Jan Bialostocki. L'Art du XVe sičcle - des Parler à Durcr. Paris: Librarie Génerale Française, 1993, especialmente o capítulo iX, "Le monde sculpté", pp. 383 e passim. 
representadas no Trésor e outras, do mesmo período? Como se constrói, no Renascimento, uma representação sobre a natureza americana e africana?

\section{Mediação cultural entre a França e Novo Mundo: algumas interpretaçōes}

Para responder sobre como ocorreram embricações entre as imagens conhecidas sobre os Novos Mundos e o Trésor, faz-se necessário pensar quais produtos culturais teriam servido de mediadores para a realização dessa escultura.

É fato que entre os moradores da Normandia, as terras longínquas eram relativamente conhecidas. Fo- ram várias vezes visitadas, observadas, estudadas, traçadas nos mapas. Dois costumes introduzidos nos primórdios das viagens atlânticas explicam como, em 1530, encontravam-se em Dieppe homens capazes de pintar e esculpir costumes de povos situados a muitas milhas de distância. Primeiro, era raro que o mestre-carapina da embarcação ou seus aprendizes não soubessem desenhar podendo, assim, retratar in loco, as imagens que descobriam e que considerassem "estranhas", diferentes, bizarras; ou, ao atracar de volta ao porto de origem, chamava-se a bordo um desenhista profissional para registrar, por meio de croquis, armas, utensílios, animais, em uma palavra, todas as singularidades que se achasse nos lugares

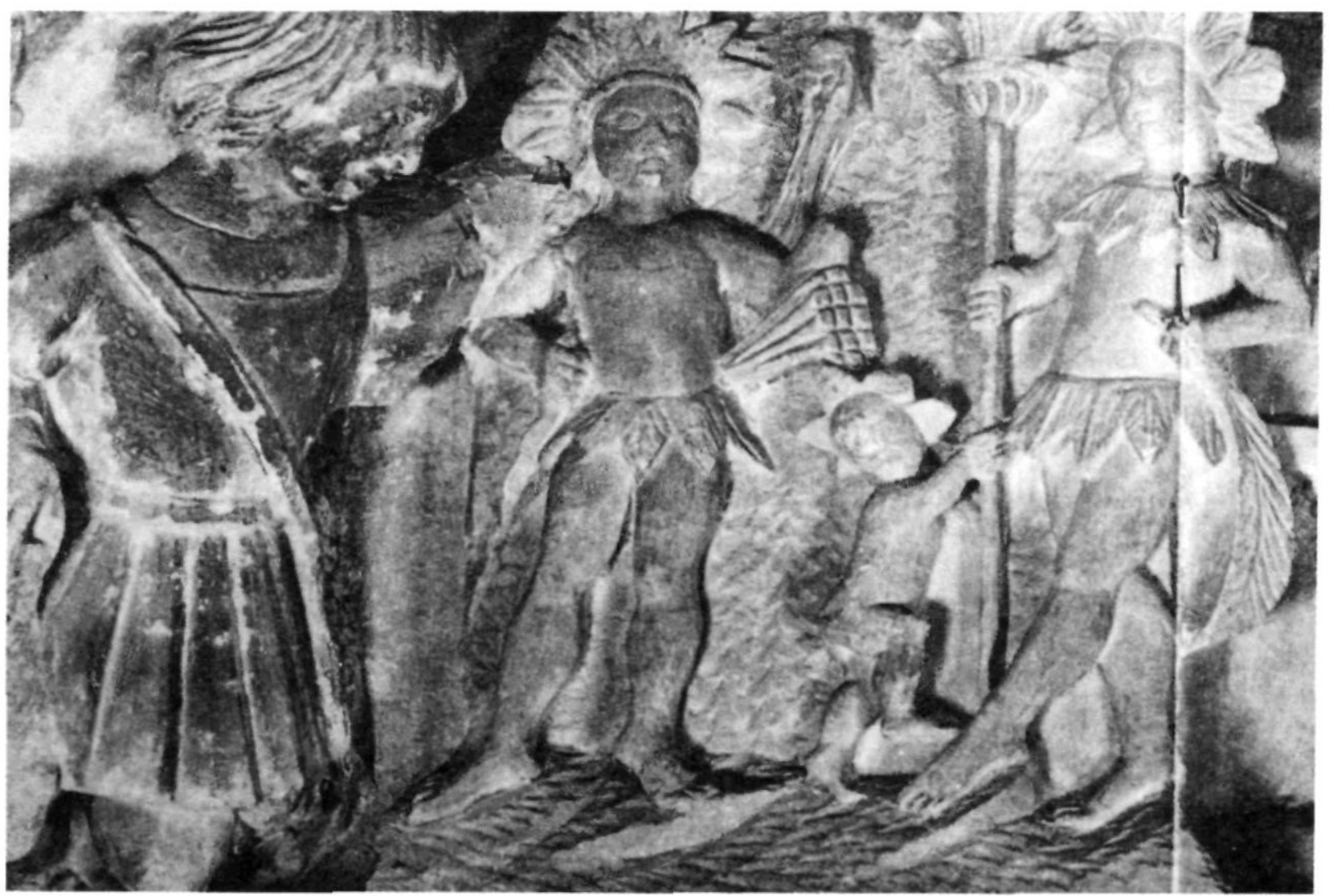

Figura 3. Detalhe da frisa dos selvagens. 
então visitados. Tais desenhos eram anexados ao relatório de viagem do capitāo e depositados no tribunal do almirantado. Se a expedição tivesse sucesso, curiosos e artistas da cidade não perdiam tempo em consultar e copiar tais desenhos.

Por outro lado, era de uso corrente entre capitāes de longo curso, trazer a bordo, como "peça de convição", os próprios "selvagens", homens, mulheres ou crianças. Tão logo chegavam, eram expostos à curiosidade pública; se fossem complacentes, eram batizados com grande cerimônia pública; depois de bem adestrados, partiam como intérpretes em outras viagens. Como o movimento de barcos era incessante, raramente não se encontravam em Dieppe "selvagens": americanos, asiáticos ou africanos, todos modelos vivos para o escultor do Trésor. Esta dupla utilização dos "selvagens" é confirmada pelo opúsculo do abade Binot-Paulmier de Gonneville, neto de Essomeriq, índio brasileiro levado para Honfleur onde estabeleceu-se e constituiu família ${ }^{23}$.

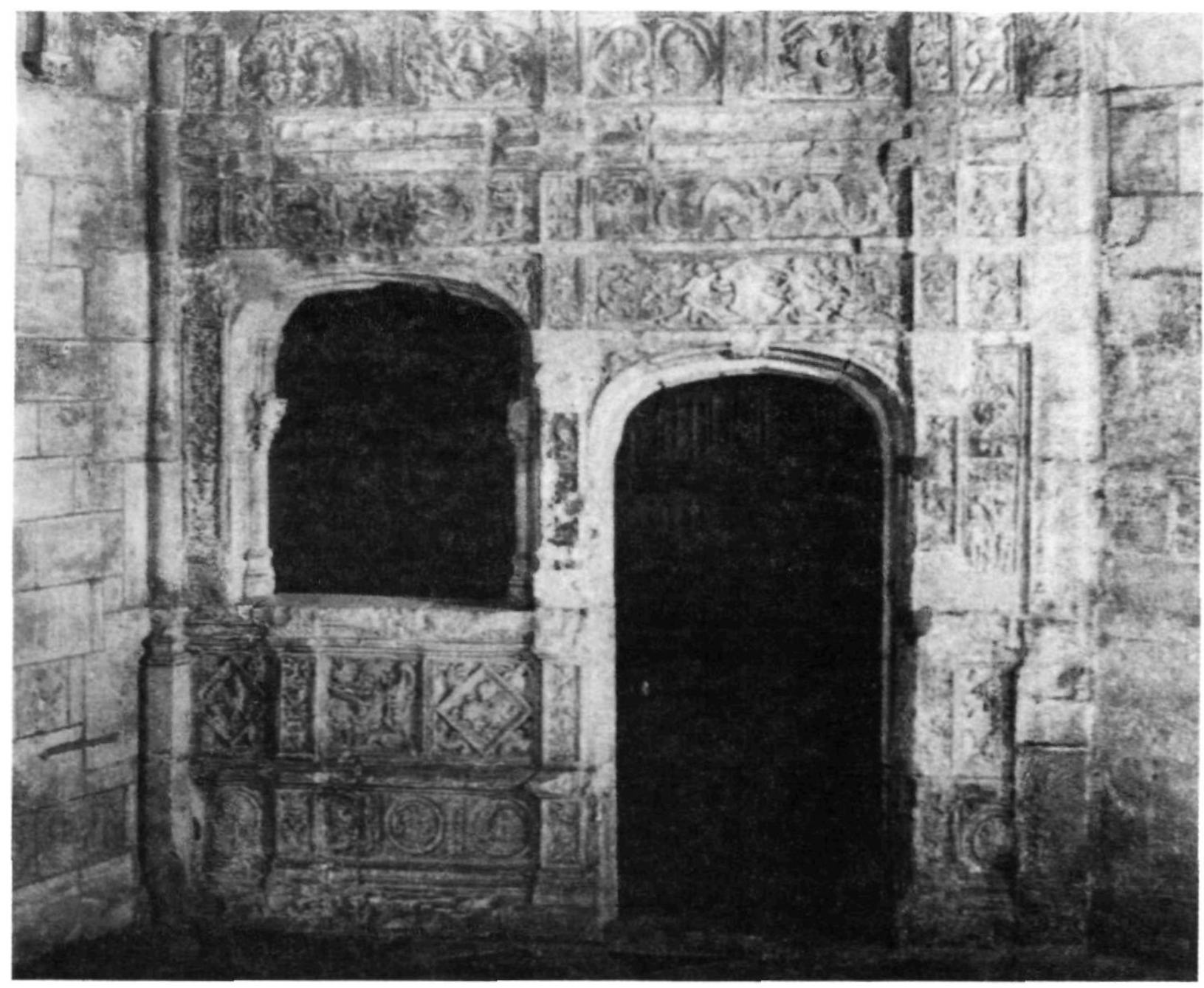

Figura 4. Oratório particular de Jehan Ango - Igreja de Saint-Jacques, Dieppe. 
Além de modelos vivos e desenhos, o escultor pode ter se beneficiado dos relatos de Parmentier, um dos mais célebres pilotos de Ango:

Au Brésil, les hommes et femmes sont nus; ils ont pour armes des arcs et des flèches dont l'extrémite porte une pointe de bois très dur ou d'os. Leurs colliers sont des espèces de chapelets ornés d'écailles de poisson. D'autres, lorqu'ils assistent à quelque banquet, se couvrent de plumes de la tête aux pieds.

Gonneville, por sua vez, descreveu-os:

Les habitants portent manteaux qui de nastes déliées, qui de peu, qui de plumasseries, avec manières de tablier ceints par-dessus les hanches, allant jusques aux genouïls pour les hommes et à my-jambes pour les femmes. les hommes portent longs cheveux ballants, avec un tour de plumasses hautes, vif-teintes et bien atournées.

Esta pintura muito convém aos personagens semi-vestidos da frisa (LEGRIS, 1918, p. 113).

Outro produto de mediação pode ter sido a pintura. Em 1479, o vêneto Gentile Bellini, conterrâneo de Verrazano e Primaticio, enviado a Constantinopla como retratista do Grăo-Turco, prolonga seus contactos com o Oriente estudando seus personagens, mores, paisagens. Em 1520, A. Dürer, de passagem por Bruxelas tem oportunidade de admirar os objetos de pluma e a suntuosa joalheria asteca que Cortês enviara a Carlos $\mathrm{V}^{24}$. Mais tarde, em Nuremberg, ocupase em decorar, nesse espírito, planisférios e um mapamundi desenhado por Stabius.

23. Incorporo aqui informaçōes extraídas de $M$. L. Vitet, op. cit., pp. 128-129. A obra de B.P. de Goneville é um opúsculo enviado ao papa Alexandre VII e ao rei de França supljcando-os a enviar uma missăo catequética a Nova-Holanda: Mémoires touchant l'établissement d'une mission chrélienne dans le troisième Monde, autrement appelé la Terre australe, méridionale, antarctique et inconnue, 1663. A dita terra austral é o Brasil.

24. Veja-se o clássico de Numa Broc. La geographic de la Renaissance, Patis, Les éditions du Comité des Travaux Historiques et Scientifiques, 1986, especialmente o capítulo XIV, "Géographie et art pictural", p. 205.
As coleçōes de viagem editadas entre 1450 e 1550 podem, igualmente, ter servido como influência: a do italiano Ramusio, dos ingleses, Hackluit e Purchas, dos flamengos De Bry e Linschoten; o primeiro, contemporâneo de Colombo e os demais, testemunhas de outras viagens. Em 1507 aparece em Vicenza sob o título Mondo Novo e Paesi novamente ritrovati da Alberico Vespuzio fiorentino, um exemplo destas importantes coleçōes. Atribuido ao compilador Montalboddo, professor de humanidades, compreende seis partes: as três primeiras são consagradas às viagens dos portugueses à Guiné e às Îndias, em particular os périplos de Cadamosto e Vasco da Gama. A quarta reproduz o Libretto de tutte navigazione de Re di Spagna, condensando fragmentos das Décadas de Pedro Martir de Anguiera. O quinto, retoma o Mundus Novus, quer dizer, a viagem de Américo Vespúcio ao Brasil e a última e sexta, dá a conhecer diversas relações portuguesas sobre o Brasil (Cabral), o Labrador (Cortereal), as feitorias da costa do Malabar, etc. (BROC, 1986, p. 27).

Uma vez reunidas as hipóteses que explicam a inspiração da frisa do Trésor de Ango, passemos a outra questão: como se constróem, no Renascimento, representaçōes sobre a natureza do americano ou do africano?

Inicialmente, é preciso sublinhar que a escolha do tema não é fortuita e nem se deve exclusivamente ao ciclo de grandes navegações que abriu, aos europeus, um horizonte de novas imagens. A bizarria do tema escora-se numa tradiçāo medieval, que, como já explicou G. Duby, incentivara os homens a olhar o mundo e sua diversidade. "A sociedade dos fins do período medieval era espontaneamente curiosa e tinha o prazer na contemplaçāo das coisas. Tinha o gosto do estranho. O exotismo abria para ela uma das portas de evasão... A cruzada fora pretexto, de fato, para maravilhosas viagens... As narrativas de viagens autênticas fizeram concorrência aos contos que teciam em redor da demanda cortês um universo de fá- 
bulas e de sonho. Os Espelho do Mundo, os Livros das Maravilhas, os Livros do Tesouro, os Bestiários apresentavam em dialecto vulgar, a descrição minuciosa de criaturas desconhecidas. Estas, ao contrário dos dragões ou dos unicómios, tinham o mérito de existir" (BROC, 1986, pp. 267-268).

Esta tradição iconográfica repousa por seu turno em uma concepção específica $\mathrm{e}$ institucional da natureza, nestes tempos: o tomismo. São Tomás interpretava a natura como um princípio de movimento que tendia a conservar e perpetuar a obra do Criador. Os antecedentes do clima da Contra-Rcforma favoreciam, igualmentc, o desabrochar de um naturalismo devoto e de uma picdadc aberta às belezas do mundo físico. Desenvolveu-se, no Renascimcnto, uma apologética fundada nas harmonias da Criação: não haveria mal nas benesses da natureza. Esse otimismo cosmológico $\mathrm{c}$ moral no interior do qual o sentido do pecado se diluía, irá contrastar com o horror ao pecado original que marcou a fé do periodo seguinte, o Clássico.

Esta representaçāo de um mundo tão adaptado às nccessidades do homem nos seus mínimos detalhes, tinha a fragilidade dos organismos excessivamente complcxos. Ela se sustentava na crença lógica da adaptação de cada uma das partes ao todo em função de uma finalidade perfeita. O mundo criado por Deus para o homem, não podia mostrar-se em desacordo com a criatura. $O$ espírito buscava harmonizar-se na unidade.

As viagens ultramarinas revelaram, contudo, a diversidade de numerosos povos que as narrativas maravilhadas dos primeiros cronistas cobriam de um prestígio lendário. Mais do que isto, os tempos difíceis do primeiro quartel do Dezesseis não se pacificavam diante das soluçōes tradicionais. A esperança residia na renúncia das idéias vigentes: a verdadeira razāo encontrava-se intacta no homem simples, o homem da Natureza. Aquele que Jehan Ango manda retratar em sua frisa, pois a natureza parecia o remé- dio para as fantasias de outros homens a quem a prometida paz da Igreja havia lançado em atrozes gucrras religosas, ou a centralização de jovens Estádos, incentivara as lutas comerciais.

Se o mundo físico, como ensina Robert Lenoble (Histoire de l'Idée de Nature, Paris, Albin Michel, 1969 , p. 283 e passim), é mais vasto do que se pensava, também o é, o mundo interior do prazer e da vida. Daí impor-se um tipo à beleza do homcm natural: 0 nu, com suas formas carnais e sutis invade a pedra $e$ o naturalismo nāo poupa esforços na escultura e na pintura, para retratar além de corpos, plantas, flores e animais em suas paisagens de origem.

Nestc cenário, negros e índios "selvagens" correspondiam simultaneamente às duas representaçōes que coexistiram neste período: herança do pensamento medieval, uma concepção vertical da Natureza que lia a unidade como una construção que subia, por degraus hierárquicos, até Deus; filha das experiĉncias modernas, uma concepção horizontal, que incorporava a diversidade das formas imprevisíveis.

Decorrente desta acepçăo, a frisa dos "sclvagens" representa o tema, caro ao Renascimento, da admirável diversidade da natureza. Jean Céard ${ }^{25}$ demonstrou como uma tal diversidadc podia aparecer como signo tangível da difusão divina no mundo, testemunhando a profusa generosidade do Criador em relação aos seus filhos. Reunida nas cosmografias ou em esculturas como a do Trésor sobre as quais expunham-se seus materiais polimorfos, a noção de diversidade convidava a celebrar a glória do Todo Poderoso, autor de tantas coisas. Um jogo etimológico muito antigo sobre a palavra grega "cosmos" associ-

25. Para uma análise mais aprofundada desta corrente de idéias, consultar a obra fundamental de Céard, La Naturc et les Prodiges. L'Insolite au XV/' sičclc, Genève, Droz, 1977, especialmente a IV parte, intitulada "Les Monstres et les Prodiges et la merveilleuse varieté des choses". Ver também Écrirc le monde ò la Renaissancc, (org.) Frank Lestringant, Caen, Paradigme, 1993. 




Figura 5. Frisa dos selvagens na igreja de Saint-Jacques, Dieppe.

ava-se a "ornamento" ou tudo o que fosse belo, prazeroso e deleitável, assimilando o universo a um espetáculo visual cuja inesgotável multiplicidade não teria limites. Deus o reservara, desde as suas origens, ao exclusivo olhar do homem para sua recreação e instrução. Esta pedagogia do Criador, que recorre à imagem - ou a imagens inumeráveis e variadas, desdobrando da base para o alto, a imensa escala dos seres - para ensinar ao espírito humano, por induçōes sucessivas, a unidade do Grande-Todo, foi por sua vez copiada pelos autores de filosofias naturais, geógrafos e artistas ${ }^{26}$, entre esses, o autor da frisa na igreja de Saint-Jacques.

Concebida ao mesmo tempo como representação visual e legível de um corpo de doutrina teologal e como marca pessoal de poder de Ango, a frisa dos selvagens permite uma possível decifraçāo do olhar

26. Empresto aqui algumas idéias de F. Lestringant, em Fortunes de la singularité à la Renaissance: la genre de l' "isolario", p. 17. que teve o homem do Renascimento sobre os Novos Mundos.

Mediador entre culturas e saberes específicos, o comerciante e armateur Jehan Ango estabelece um curioso sistema de correspondências, peculiares ao momento do Renascimento. Ele se dedica à prática devocional celebrando a glória de Deus na inesgotável riqueza do universo. Os selvagens do Trésor eram a prova viva desta pedagogia do Criador e por isto ele partilha, numa forma de religiosidade urbana e coletiva, sua representação com a comunidade

Mediadores culturais entre um tempo e outro do tempo do desprezo eminentemente clerical a tudo o que fosse profano, para aquele do otimismo laico, da alegria franciscana pelas coisas vividas e percebidas na experiência cotidiana, do prazer na contemplação do estranho - os "selvagens" na igreja revelam a ambigüidade típica de um Renascimento, mediador - ele também -, entre o prazer e a angústia de viver frente à natureza e a incapturável diversidade das coisas. 


\section{Bibliografia}

BAZIN, Pierre. Conservatér du Musée de Dieppe. "Points de Départs". Vicilles Maisons Françaises - Patrimoinc Historiquc, $n^{2} 147$, pp. 26-31.

BIALOSTOCKI, Jan. L'Art du X'Ve sidcle-des Parler a Durer. Paris: Librarie Génerale Française, 1993, especialmente o capítulo IX, "Le monde sculpté", p. 383 e passim.

DEL PRIORE, Mary Lucy Murray. "Retrato da América quando Jovem". Estudos Históricos n"9, Amética, Fundaçāo Banco do Brasil/Editora Fundaçāo Getúlio Vargas, 1992 , pp. 3-13.

DELUMEAU, Jean. A Civilização do Renascimento. Lisboa: Editorial Estampa, 1984, vol. 1, p. 60

DUBY, Gcorges. O Tcmpo das Catedrais - A Artc $c$ a Socicdadc. Lisboa: Editorial Estampa, 1979, especialmente o capilulo 8, "Homens Novos", p. 191 e passim.

DUPUIS, François. Jchan Ango - Navigation et Renaissance à Dicppc. litinéraires du Patrimoine $n^{2} 17,1992$, p. 4.

FEBVRE, Lucien. Au cocur religieux du XVI* siccle. Paris: EHESS, 1983, p. 53.

GARRISON, Janinc. Royaumc, Renaissance et Réforme 1483-1559. Paris: Seuil, 1991, pp. 27-37
GODINHO, Vitorino Magalhāes. Os Descobrimentos e a Economia Mundial. Lisboa: Editoral Presença, 2 vols., 1963-1971.

LE GOFF, Jacques \& RÉMOND, René. Histoirc de la France Religicuse $-X I V * X V I I / V^{*}$ siccles. Paris: Seuil, 1988, vol. II, p. 206.

LEGRIS, A. L'Église Saint-Jacques de Dieppe - Notice Historique et Descriptive. Dieppe: G. Letremble Libraire, 1918, pp. 107.117.

MAURO, Frédéric. Le XVI sièclc curopécn. Aspects Economiqucs. Paris: PUF, 1966, pp. 213-214.

MERRIEN, Jean. Histoire des Carsaires. Paris: Amio:Dumont, 1954.

PELLEGRIN, Nicole. "Vêtements de peau $(x)$ et de plumes: la nudité des indiens". Voyager à la Renaissance. Paris: Maisonneuve \& Larose, 1987.

THOMAZI, A. Les flottes de l'Or - Histoirc des Galions d'Espagne. Paris: Payot, 1978, pp. 36-52.

VITET, M. L. Histoire des Anciennes Villes de France. Paris, Alexandre Mesnier, 1833, pp. 112-131.

Endereço da Autora: Departamento de História - FFLCH/USP - Av. Professor Lineu Prestes, 338 - Cidade Universitária - CEP 05508-900 - Sāo Paulo - Brasil - FAX (011) 818-3150 